\title{
Unraveling the Digital Literacy Paradox: How Higher Education Fails at the Fourth Literacy
}

\author{
Meg Coffin Murray and Jorge Pérez \\ Kennesaw State University, Kennesaw, GA, USA
}

mcmurray@kennsaw.edu; jperez@kennesaw.edu

\begin{abstract}
Governments around the globe are recognizing the economic ramifications of a digitally literate citizenry and implementing systemic strategies to advance digital literacy. Awareness of the growing importance of digital literacy in today's workplace coexists paradoxically with apparent foot-dragging on the part of many universities in assessment and amplification of these important competencies. This paper makes a case for digital literacy, presents models of the complex construct, and presents the results of a digital literacy assessment administered to students enrolled in a senior seminar course at a regional university in the United States. Reflection on the study results evoked our mantra that exposure does not equal understanding with regard to students' daily interaction with digital technologies. A strong case is made for comprehensive strategies that reach back to the youngest students and ensure that college graduates enter the modern workforce armed with critical technology competencies that have been termed the fourth literacy.
\end{abstract}

Keywords: digital literacy, technology literacy, ICT, digital skills, digital divide.

\section{Introduction}

Awareness of the growing importance of digital literacy in today's workplace coexists paradoxically with apparent foot-dragging on the part of many universities in assessment and amplification of these important competencies. Moreover, many employers and educators acknowledge that institutions of higher education are not adequately preparing college graduates in the area of digital literacy (Duggan, 2013).

Digital literacy is widely acknowledged as essential and germane in today's highly competitive and global markets. In fact, digital literacy has been deemed an essential life skill (DG information Society and Media Group, 2008). But many institutions of higher education have not fully embraced digital literacy as a foundational literacy on par with reading, writing and arithmetic. At most universities, digital literacy is either taken for granted or assumed to be at an adequate level

Material published as part of this publication, either on-line or in print, is copyrighted by the Informing Science Institute. Permission to make digital or paper copy of part or all of these works for personal or classroom use is granted without fee provided that the copies are not made or distributed for profit or commercial advantage AND that copies 1) bear this notice in full and 2) give the full citation on the first page. It is permissible to abstract these works so long as credit is given. To copy in all other cases or to republish or to post on a server or to redistribute to lists requires specific permission and payment of a fee. Contact Publisher@InformingScience.org to request redistribution permission. rather than being assessed, remediated and amplified.

The academy must address this inadequacy in incorporating digital literacy as a core, foundational competency. Information technology is a high-velocity field, and defining and measuring a set of dynamic IT skills is both challenging and costly. Nonetheless, higher education must escape traditional approaches to relatively static competencies if it is 
to embrace the economic and social drivers of the future. Digital literacy does not diminish the standing of traditional literacies or the liberal arts. In contrast, we argue that digital literacy is both inseparable from the liberal arts of today and fundamental to modern reading, writing and arithmetic. This paper presents a study that underscores the salience of digital literacy and contributes to the dialog on its assessment and remediation.

\section{Defining Digital Literacy}

Educators have sought to define and measure computer literacy for decades. In this quest, the construct has been referred to by many names, often combinations of terms such as computer, information, technology or digital matched with literacy, proficiency, competency or fluency. Of late, the term digital literacy has gained prominence around the globe. As Martin (2006) stated, digital literacy is an integrating, but not overarching, concept that "focuses upon the digital without limiting itself to computer skills and which comes with little historical baggage" (p. 3).

The first published use of the term digital literacy dates to 1997 and is attributed to Paul Gilster (1997). He noted that digital literacy is a special kind of mindset, "about mastering ideas - not keystrokes" (p. 15). Based on this precept, established and accepted definitions of digital literacy are built on three principles:

- skills and knowledge to access and use a variety of hardware devices and software applications

- adeptness to understand and critically analyze digital content and applications

- ability to create with digital technology (Media Awareness Network, 2010).

Using these principles as a foundation, the European Commission defines competencies related to digital literacy verbosely and thoroughly as the "knowledge, skills, attitudes (thus including abilities, strategies, values and awareness) that are required to use ICT and digital media to perform tasks; solve problems; communicate; manage information; collaborate; create and share content; and build knowledge effectively, efficiently, appropriately, critically, creatively, autonomously, flexibly, ethically, reflectively for work, leisure, participation, learning, socializing, consuming, and empowerment" (Ferrari, 2013, p. 3). In the context of higher education, the UK-based JISC refers to digital literacy as "the skill in using digital tools to undertake academic research; writing and critical thinking; as part of personal development planning; and as a way of showcasing achievements" (JISC, 2013, para. 3). Whatever the case, comprehensive definitions of digital literacy go well beyond skill-based and incorporate critical thinking and problem-solving, capturing the notion that digital literacy is ultimately about the ability to effectively solve problems in a technology-rich environment (Organisation for Economic Co-operation and Development, 2013).

\section{Models of Digital Literacy}

Early models of digital literacy often focused on a specific set of ICT skills. As the digital environment expanded, models of digital literacy followed suit, often morphing into collections of related skills, with each set identified as a separate literacy. In addition to IT literacy (operational skills in using computing technologies), these multi-literacies include concepts such as information literacy (evaluation of information and sources), media literacy (ability to deal with digital information in a variety of media) and internet/network literacy (effective use of the Internet and other networked resources) (Bawden, 2008). More recent models represent not only a convergence of the multi-literacy approach but also expose the relative nascence of the digital literacy construct.

Van Deursen and Van Dijk (2009) proposed a digital skills model comprised of four categories: operational skills or skills necessary to operate computer hardware and software; formal skills or 
the ability to understand and handle formal characteristics of computer networks and web environments; information skills or the ability to select, evaluate and process information; and strategic skills or the ability to employ ICT to reach a goal. Martin and Grudziecki (2006) extend this model into three stages of digital literacy development: competence, use and transformation. Digital competence represents the foundation where basic skills are acquired and developed and attitudes are formulated. In essence digital competence consists of knowledge, skills and attitudes (Martin \& Grudziecki, 2006). Digital usage represents the application of digital competence within a specific context such as a discipline, knowledge domain or professional arena. This is the stage where digital literacy is put into action, where digital competence is used to solve an identified problem. Martin and Grudziecki (2006) see this as the central and most crucial level of digital literacy - it is what defines one as digitally literate - but it also forms the triggers that propel digital transformation. Digital transformation is where transformative change happens, where creativity and innovation are enabled.

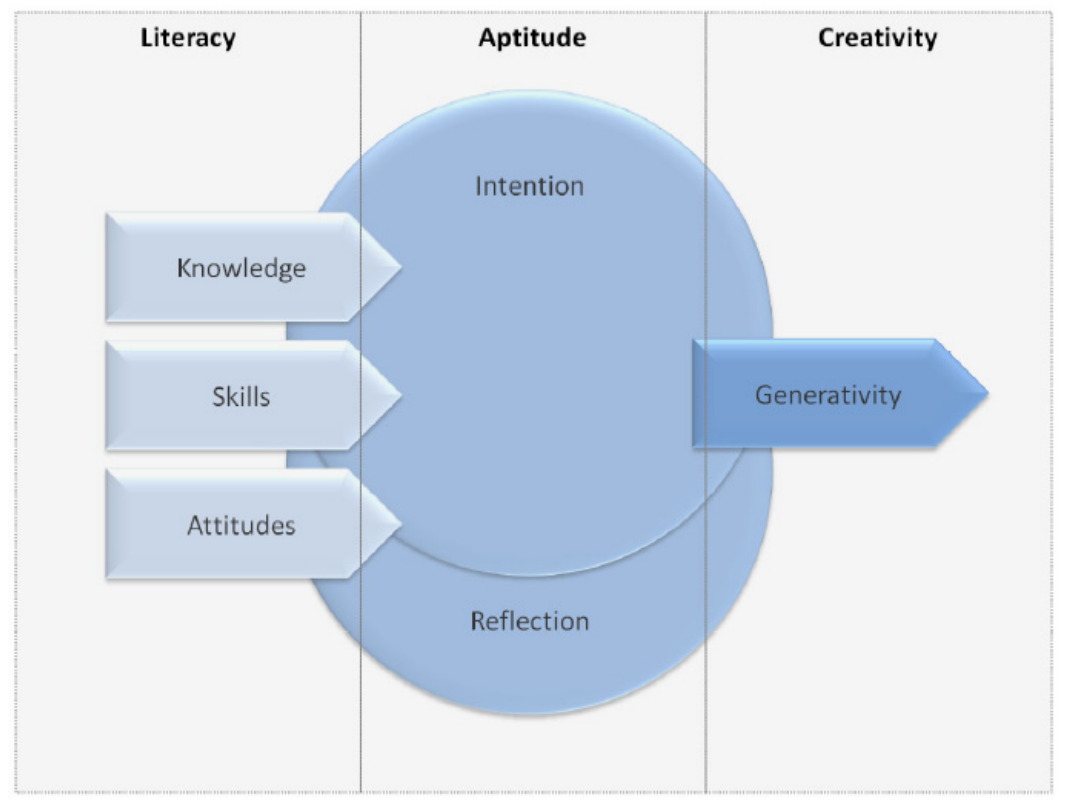

Figure 1. A Model of Digital Literacy

Adapted from "Generativity: The New Frontier for Information and Communication Technology Literacy" by J. Pérez and M. Murray, 2010, Interdisciplinary Journal of Information, Knowledge and Management, 5, p. 132. Copyright 2010 by Informing Science Institute.

The broad model proposed by Pérez and Murray (2010) incorporates intention and reflection as elements in the digital literacy construct (Figure 1). In this model, "knowledge, skills and attitudes coalesce in the context of reflective self-awareness and purposeful intent to allow a computer user to achieve generativity - the ability to generate new skills and knowledge that form the basis for creativity" (Pérez \& Murray, 2010). The dimensions of literacy, aptitude, and creativity are overlaid on the model to illustrate movement from foundational to self-aware to innovative interactions with computer technologies. Literacy encompasses knowledge, skills, and attitudes; aptitude captures reflection and intention; generativity connotes the potential for creativity. Although the model shows movement from literacy to aptitude to creativity, there is no intent to imply linearity in the relationships among these complex constructs. The overlay of literacy, aptitude, and creativity is meant to give meaning to the complex, iterative processes by which users learn about, interact with, assimilate and transfer information technology artifacts and concepts processes that are neither linear nor deterministic. 
The recent models described above have in common a holistic perspective, wherein the complex digital literacy construct is conceived as more than the attainment of a set of basic skills. The landscape has moved far beyond functional definitions of digital literacy focused on operational skills (Buckingham, 2006; Martin, 2005). Perhaps the notion of literacy itself is constraining or has a pejorative connotation. Regardless, the models clearly go beyond functional literacy to encompass problem-solving, creativity and generativity. This presents a complex but not novel challenge for institutions of higher education, wherein a similar process played out vis-à-vis the evolution of the fundamental literacies of reading, writing and arithmetic.

The clearest articulation of an educational institution's approach to digital literacy manifests in its curriculum. As Martin (2006) notes, there is a set of common skills to which all prospective scholars and educated persons should aspire. Students who are not digitally literate are less effective in their studies and less employable (JISC, 2012a). A key concept is that digital literacy must be taught. According to Helen Beetham from the JISC Developing Digital Literacies Programme, digital literacy stands at "the intersection between digital knowhow and academic practice" (JISC, 2012a p. 2). Many students entering the university today have a high level of exposure to digital technologies and media. However, they are not prepared to cross the bridge between personal and academic use of technology. As academic knowhow is gained through formal education, so too must technological prowess be gained through structured learning experiences.

\section{Need for Digital Literacy}

In the age of ubiquitous computing, digital literacy has become increasingly critical to success in any educational discipline or occupation. Critical information technology competencies are often taken for granted by educators and employers, putting at a clear disadvantage many students and workers who lack requisite computing and Internet skills (Katz \& Macklin, 2007). Students today are certainly exposed to and immersed in digital media. But their ability to use information technology to solve common business and real-world problems is frequently over-estimated. Noting the importance of information technology as a fundamental driver of societal and economic change, many countries are starting to take action at a national level. While many developed countries have formulated digital literacy initiatives, progress in the implementation of these strategies varies greatly. For instance, Japan and South Korea have mature digital literacy strategies demonstrated by both broad-based societal access to information and communication technologies and scores on international assessment tests such as the OECD Program for International Student Assessment (Organisation for Economic Co-operation and Development, 2011) and the OECD Program for the International Assessment of Adult Competencies (Organisation for Economic Co-operation and Development, 2013). The European Commission also has a well-defined digital agenda (European Commission, 2013), and the UK recently completed a nation-wide initiative aimed at promoting inclusion of holistic strategies and organizational approaches to developing digital literacy in higher education (JISC, 2012). The United States has a federal government inter-agency working group that aims to advance digital literacy across all age groups and learning venues; but beyond providing an online portal to resource materials, the U.S. has not moved forward with a strategic digital literacy plan. Interestingly, the U.S. Department of Commerce cites digital literacy as a necessary prerequisite job skill and Internet-based activity as a primary contributor to the U.S. economy (U.S. Department of Commerce, 2011; National Telecommunications and Information Administration, n.d.).

Canada has yet to institute a national digital literacy strategy but advocates calling for such an initiative are clear in their assertion that a decline in Canada's performance in the digital economy is directly tied to the absence of such an effort: "Digital literacy is that next step which gives Canadians the adaptive abilities they need to participate fully in the global digital society. It guarantees they will benefit from the digital economy and derive new opportunities for employment, 
innovation, creative expression, and social inclusion." (Media Awareness Network, 2010, p.4). That is, developing a national model of digital literacy and implementing a strategy that identifies barriers to digital literacy and addresses ways to overcome those barriers are essential to a country's economic stability and sustainability (Media Awareness Network, 2010).

Australia has a somewhat fractured national digital literacy strategy. A recent report by Innovation \& Business Skills Australia, an industry skills council funded by the Australian government, noted that national efforts to provide affordable access to ICT are underway in the absence of initiatives to improve ICT skills (Innovation and Business Skills Australia, 2013). The report posits that non-progression of digital literacy could work to amplify, rather than reduce, the country's digital divide. A government report, Transforming Australia's Higher Education System (DEEWR, 2009), reinforces the need for ICT skills in graduates. "A strategy is needed in Australia that will build upon the initiatives in the school-sector and result in university graduates who will meet the national and workplace needs" (Duncan-Howell, 2012, p. 831).

Europe has long recognized the socio-economic impact of ICT. The European Commission was one of the first government entities to recognize the importance of digital literacy, noting that it is an essential competency for members of a knowledge-based society:

"The ability to use ICT and the Internet becomes a new form of literacy - 'digital literacy'. Digital literacy is fast becoming a prerequisite for creativity, innovation and entrepreneurship and without it citizens can neither participate fully in society nor acquire the skills and knowledge necessary to live in the 21 st century" (European Commission, 2003, p. 3).

Not surprisingly, digital literacy is a major component of the European Union's Europe 2020 strategic plan. The Digital Agenda for Europe (DAE) is one of seven major initiatives designed to move Europe toward a sustainable economic future. ICT was cited as enabling success, spurring innovation and economic growth, and contributing to improvements in the quality of life (European Commission, 2010). The Digital Agenda for Europe represents the most comprehensive government-sponsored initiative to address the digital needs of its citizens. The Agenda identifies 102 action items organized into seven pillars, each focused on a different area: from the provision of resources to identification of standards for interoperability to investment in research. Pillar VI specifically focuses on enhancing digital literacy and ICT skills. As part of this work, a set of measures, or what they term indicators, of digital competence were developed. In all, 21 competencies organized into five areas were identified: information, communication, content-creation, safety and problem-solving (Ferrari, 2013). This framework of digital competence is currently under review by European Union member states. Once accepted, it will become the foundation for developing a 'roadmap' for the incorporation of digital literacy in all levels of formal education.

The United Kingdom is taking direct action to infuse digital literacy in post-secondary education, tasking universities with developing digitally literate graduates. Student expectations, employer demands and ensuring the competiveness of the UK workforce in global markets are all drivers of the UK stance on digital literacy (JISC, 2012a). Even as the British government implemented austerity measures that resulted in severe cuts to the British higher education system, JISC has remained highly active, embarking upon a major digital literacy project in higher education. Originally created as the Joint Information Systems Committee tasked with providing leadership in implementation of ITC in universities, JISC has evolved into an independent, charitable, nongovernment organization. JISC's Developing Digital Literacies Programme is designed to promote "the development of coherent, inclusive and holistic institutional strategies for developing digital literacies for all staff and students in UK further and higher education" (JISC, 2012a, p. 1). The result of this work will be a comprehensive set of resources, such as best practices and case 
studies, which can be used by institutions as they develop or mature their own programs. The Programme is work is a major, important step toward institutionalizing digital literacy in higher education. The UK has it right. The attainment of digital literacy cannot be left to chance, and the digitally illiterate will be left behind in a digital world. As stated by JISC (2012b), "Universities and Colleges have a responsibility to develop graduates who can thrive in an era of digital information and communication" (para. 1).

This paper presents the results of a digital literacy assessment administered to students enrolled in a senior seminar course at a regional university in the United States. The university does not require all students to complete a digital literacy course; however, some majors do require such a course. Leaving aside for now the broader implications of such an approach, we will note only that many students are left to self-monitor development of their digital literacy. The digital literacy assessment addresses functional knowledge and skills as well as critical thinking. However, it focuses primarily on operational rather than higher-order uses of technology. As noted above, higher-order thinking and problem solving are ultimate goals of post-secondary education; nonetheless, generative abilities cannot exist in the absence of a solid functional foundation. Assessment is clearly central to understanding the foundations upon which students build their education.

\section{Methodology}

Students enrolled in a senior-level seminar course were asked to complete a digital literacy assessment. The capstone course provides a structure for students to assess their undergraduate experience and prepare for the transition to graduate school or the workforce; technology is not the focus of the course. Students enrolled in the course must be in their final year of study and preparing for graduation. The course is open to all majors. An implied assumption exists that students graduating from the university have attained skills and competence in information technologies, and as such, the university graduate is, by nature, digitally literate.

The assessment instrument administered to the students consisted of 15 multiple-choice questions, each with five possible responses. Items in the assessment represent three broad content areas: hardware and operating systems concepts; application software; and the Internet and information literacy. For the most part, items on the assessment were knowledge or skill-based. Below is one item from the instrument that aims to gauge understanding of the difference between storage and memory in computers:

A computer's is comparable to a human's short-term memory.
a. ROM
b. RAM
c. internal hard drive
d. external hard drive
e. $\mathrm{CPU}$

Another item from the instrument attempts to ascertain if a respondent understands the suitability of various file formats for a specific application:

You are assigned the task of electronically distributing a 300-page user manual to a global network of affiliates. You know that some recipients will print the manual, whereas others will view it on a computer screen. Which of the following file formats is best suited for your task of distributing the file?
a. Hypertext Markup Language
b. Microsoft Word
c. Plain Text 


\section{d. Portable Document Format \\ e. Rich Text Format}

The following item that appears in the instrument addresses the ability to effectively and efficiently search the World Wide Web for information, which is one important aspect of a broader set of abilities often referred to as information literacy:

Which of the following would be the best to enter into a search engine on the Web to find information about organic chemistry?
a. organic OR chemistry
b. organic AND chemistry
c. organic NOT chemistry
d. organic chemistry
e. "organic chemistry"

The sample items above, one from each of the three broad content categories, exemplify the types of questions that comprise the instrument that appears in the Appendix.

Participation in the study was voluntary and student responses were not graded. Students were motivated to complete the assessment to gain more understanding of their own information technology competence. The assessment was administered four concurrent semesters beginning spring 2010.

The demographics of students who participated in the assessment (Table 1) were fairly consistent across four semesters. In each class, a majority of students were female and of typical age for undergraduate college students in the U.S. Students majoring in a variety of disciplines comprised the group, although communication majors represented just over a third of the respondents.

Table 1. Student demographics

\begin{tabular}{|c|c|c|c|c|c|c|}
\hline & $\begin{array}{c}\text { Spring } \\
2010\end{array}$ & $\begin{array}{c}\text { Fall } \\
2010\end{array}$ & $\begin{array}{c}\text { Spring } \\
2011\end{array}$ & $\begin{array}{r}\text { Fall } \\
2011 \\
\end{array}$ & All & $\begin{array}{l}\% \text { of } \\
\text { total }\end{array}$ \\
\hline & \multicolumn{3}{|c|}{ Gender } & & & \\
\hline Female & 21 & 20 & 25 & 24 & 90 & $65.22 \%$ \\
\hline Male & 14 & 7 & 8 & 11 & 40 & $28.99 \%$ \\
\hline not reported & 7 & & 1 & & 8 & $5.80 \%$ \\
\hline \multirow[t]{2}{*}{ Total } & 42 & 27 & 34 & 35 & 138 & \\
\hline & \multicolumn{3}{|c|}{ Age } & & & \\
\hline $20-23$ & 22 & 17 & 21 & 20 & 80 & $57.97 \%$ \\
\hline $24-27$ & 7 & 5 & 7 & 6 & 25 & $18.12 \%$ \\
\hline $28-31$ & 2 & 2 & 2 & 2 & 8 & $5.80 \%$ \\
\hline $32-35$ & 1 & 2 & 0 & 2 & 5 & $3.62 \%$ \\
\hline over 35 & 2 & 1 & 2 & 3 & 8 & $5.80 \%$ \\
\hline not reported & 8 & & 2 & 2 & 12 & $8.70 \%$ \\
\hline Total & 42 & 27 & 34 & 35 & 138 & \\
\hline
\end{tabular}




\begin{tabular}{|c|c|c|c|c|c|c|}
\hline & $\begin{array}{c}\text { Spring } \\
2010\end{array}$ & $\begin{array}{l}\text { Fall } \\
2010 \\
\end{array}$ & $\begin{array}{c}\text { Spring } \\
2011 \\
\end{array}$ & $\begin{array}{r}\text { Fall } \\
2011 \\
\end{array}$ & All & $\begin{array}{l}\% \text { of } \\
\text { total }\end{array}$ \\
\hline & \multicolumn{3}{|c|}{ Major } & & & \\
\hline Business & 3 & 3 & 8 & 4 & 18 & $13.04 \%$ \\
\hline Computing & 2 & 2 & & 1 & 5 & $3.62 \%$ \\
\hline Criminal Justice & 2 & & & & 2 & $1.45 \%$ \\
\hline Communications & 9 & 10 & 13 & 15 & 47 & $34.06 \%$ \\
\hline Education & 1 & & & & 1 & $0.72 \%$ \\
\hline English & & & & 1 & 1 & $0.72 \%$ \\
\hline $\begin{array}{l}\text { Exercise/Health Sci- } \\
\text { ence }\end{array}$ & 2 & & 1 & & 3 & $2.17 \%$ \\
\hline Fine Arts & & 1 & 1 & 3 & 5 & $3.62 \%$ \\
\hline Human Services & & 2 & 5 & 5 & 12 & $8.70 \%$ \\
\hline Integrated Studies & & 1 & & 3 & 4 & $2.90 \%$ \\
\hline Nursing & & 1 & & 1 & 2 & $1.45 \%$ \\
\hline Psychology & 5 & 2 & 3 & 1 & 11 & $7.97 \%$ \\
\hline Physical Sciences & 5 & 5 & 2 & 1 & 13 & $9.42 \%$ \\
\hline not reported & 13 & & 1 & & 14 & $10.14 \%$ \\
\hline Total & 42 & 27 & 34 & 35 & 138 & \\
\hline
\end{tabular}

\section{Findings}

Student scores on the assessment across the four semesters under review were compared to ascertain whether differences existed among the groups. Figure 2 shows scores for each semester. Although scores were somewhat lower after the first semester, there was little variation; the difference was not statistically significant as analyzed via single factor ANOVA test $(\mathrm{F}(3,134)=$ $0.528354, \mathrm{p}=.05)$. Since no significant difference was found between the groups, the remaining analysis was done in aggregate, combining student scores from all semesters.

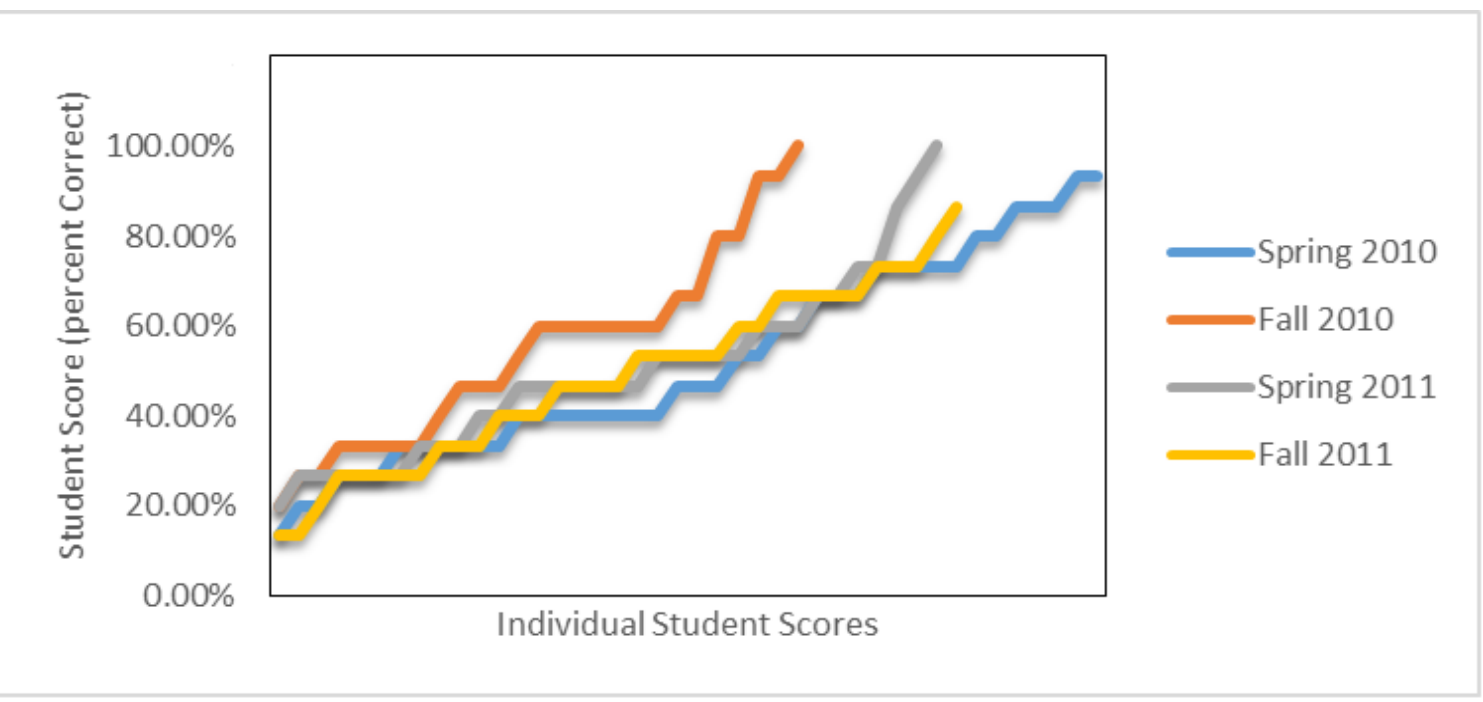

Figure 2. Student ICT assessment scores by semester 
Overall scores for all students are presented in Figure 3. The average score overall was $51 \%$. While all students answered at least one question correctly, $52 \%$ of the students answered more than half of the questions incorrectly. Only $12 \%$ of the students answered $80 \%$ or more of the questions correctly. If the typical letter grade scale were applied to the assessment ( 60 and below $=\mathrm{F}, 61-70=\mathrm{D} ; 71-80=\mathrm{C} ; 81-90=\mathrm{B} ; 81-100=\mathrm{A}$ ), $72 \%$ of the students would have received a failing grade, nine percent would have barely passed, seven percent would have earned a $\mathrm{C}$, seven percent would have earned a $\mathrm{B}$, and five percent would have received an $\mathrm{A}$. The different colors in Figure 3 correspond to letter grades.

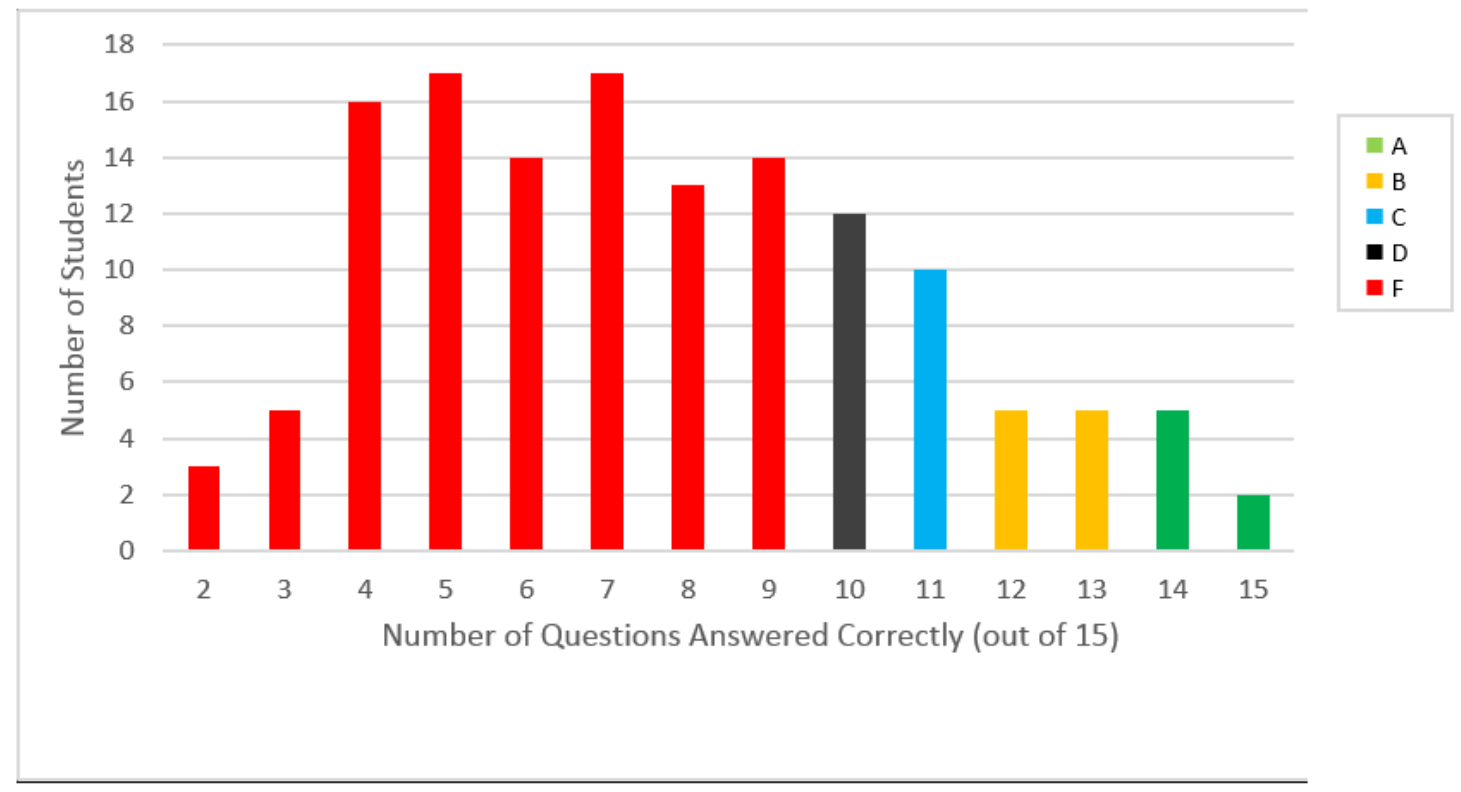

Figure 3. ICT assessment scores for all students color coded by letter grade

Seventeen students out of 138 received a score of 80 or higher (12 questions answered correctly). An analysis of these students revealed a wide spread in demographic attributes, including the semester the assessment was taken, age and major. A majority of these students $(71 \%)$ were male. Only two students answered all questions correctly. One of these students was a 22 year-old female who took the assessment in fall 2010. The other student was a 24 year-old male who took the assessment in spring 2011. Interestingly, though not statistically meaningful, both of these students were accounting majors.

The brief assessment instrument (Appendix) consists of 15 multiple-choice questions, each with five possible responses. Items in the assessment represent three broad content areas: hardware and operating systems concepts; application software; and the Internet and information literacy. The frequency and percent for each response to each question is presented in Table 2, wherein response percentages of correct answers are highlighted in gray.

As is evident in Table 2, Internet searching is the only item on which the correct response was not selected by a majority of respondents. This question (Internet - search engine) addresses the use of Boolean operators to conduct a web-based search. The correct answer was chosen by more than half of the respondents on nine items; only on three questions was the correct response selected by more than $60 \%$ of the students. Also noteworthy is that for all but two of the test items, each distractor option (an incorrect response) was chosen by at least one student. A cursory interpretation of this result, as well as the variability of responses chosen across all items, suggests that the distractors were, well, adequately distracting. The graphical representation shown in Fig- 
ure 4 depicts student responses for each answer option. The five possible options - A,B,C,D,E are displayed by color. Correct responses are displayed in black.

Table 2: Student responses to ICT assessment instrument

\begin{tabular}{|c|c|c|c|c|c|c|c|c|c|c|c|c|}
\hline \multirow{3}{*}{ Question Content Area } & \multicolumn{12}{|c|}{ Frequency/Percent Answering Each Response Option } \\
\hline & $\mathbf{A}$ & & B & & $\mathbf{C}$ & & D & & $\mathbf{E}$ & & NA & $\mathbf{N}$ \\
\hline & $\mathbf{F}$ & $\%$ & $\mathbf{F}$ & $\%$ & $\mathbf{F}$ & $\%$ & $\mathbf{F}$ & $\%$ & $\mathbf{F}$ & $\%$ & $\mathbf{F}$ & \\
\hline General (PC configuration) & 29 & $21.3 \%$ & 21 & $15.4 \%$ & 7 & $5.1 \%$ & 64 & $47.1 \%$ & 15 & $11.0 \%$ & 2 & 136 \\
\hline $\begin{array}{l}\text { Processing(Binary number } \\
\text { system) }\end{array}$ & 13 & $9.6 \%$ & 7 & $5.1 \%$ & 52 & $38.2 \%$ & 49 & $36.0 \%$ & 15 & $11.0 \%$ & 2 & 136 \\
\hline Memory (RAM) & 13 & $9.5 \%$ & 87 & $63.5 \%$ & 21 & $15.3 \%$ & 5 & $3.6 \%$ & 11 & $8.0 \%$ & 1 & 137 \\
\hline Hardware (motherboard) & 72 & $52.6 \%$ & 23 & $16.8 \%$ & 34 & $24.8 \%$ & 0 & $0.0 \%$ & 8 & $5.8 \%$ & 1 & 137 \\
\hline $\begin{array}{l}\text { Operating System (Device } \\
\text { Driver) }\end{array}$ & 10 & $7.4 \%$ & 8 & $5.9 \%$ & 102 & $75.0 \%$ & 10 & $7.4 \%$ & 6 & $4.4 \%$ & 2 & 136 \\
\hline Security (Phishing) & 9 & $6.5 \%$ & 61 & $44.2 \%$ & 40 & $29.0 \%$ & 27 & $19.6 \%$ & 1 & $0.7 \%$ & 0 & 138 \\
\hline $\begin{array}{l}\text { File System (filename } \\
\text { extension) }\end{array}$ & 9 & $6.6 \%$ & 22 & $16.2 \%$ & 29 & $21.3 \%$ & 10 & $7.4 \%$ & 66 & $48.5 \%$ & 2 & 136 \\
\hline Internet (cookies) & 12 & $8.7 \%$ & 29 & $21.0 \%$ & 22 & $15.9 \%$ & 74 & $53.6 \%$ & 1 & $0.7 \%$ & 0 & 138 \\
\hline Productivity (spreadsheet) & 7 & $5.1 \%$ & 17 & $12.5 \%$ & 31 & $22.8 \%$ & 76 & $55.9 \%$ & 5 & $3.7 \%$ & 2 & 136 \\
\hline $\begin{array}{l}\text { Software (application-open } \\
\text { source) }\end{array}$ & 52 & $38.5 \%$ & 5 & $3.7 \%$ & 10 & $7.4 \%$ & 3 & $2.2 \%$ & 65 & $48.1 \%$ & 3 & 135 \\
\hline Internet (search engine) & 27 & $19.7 \%$ & 34 & $24.8 \%$ & 3 & $2.2 \%$ & 45 & $32.8 \%$ & 28 & $20.4 \%$ & 1 & 137 \\
\hline Internet (WWW protocol) & 40 & $29.0 \%$ & 92 & $66.7 \%$ & 0 & $0.0 \%$ & 2 & $1.4 \%$ & 4 & $2.9 \%$ & 0 & 138 \\
\hline Security (wireless) & 11 & $8.1 \%$ & 30 & $22.1 \%$ & 13 & $9.6 \%$ & 10 & $7.4 \%$ & 72 & $52.9 \%$ & 2 & 136 \\
\hline Productivity (database) & 76 & $55.9 \%$ & 10 & $7.4 \%$ & 10 & $7.4 \%$ & 34 & $25.0 \%$ & 6 & $4.4 \%$ & 2 & 136 \\
\hline File Format (pdf) & 9 & $6.5 \%$ & 28 & $20.3 \%$ & 6 & $4.3 \%$ & 72 & $52.2 \%$ & 23 & $16.7 \%$ & 0 & 138 \\
\hline
\end{tabular}

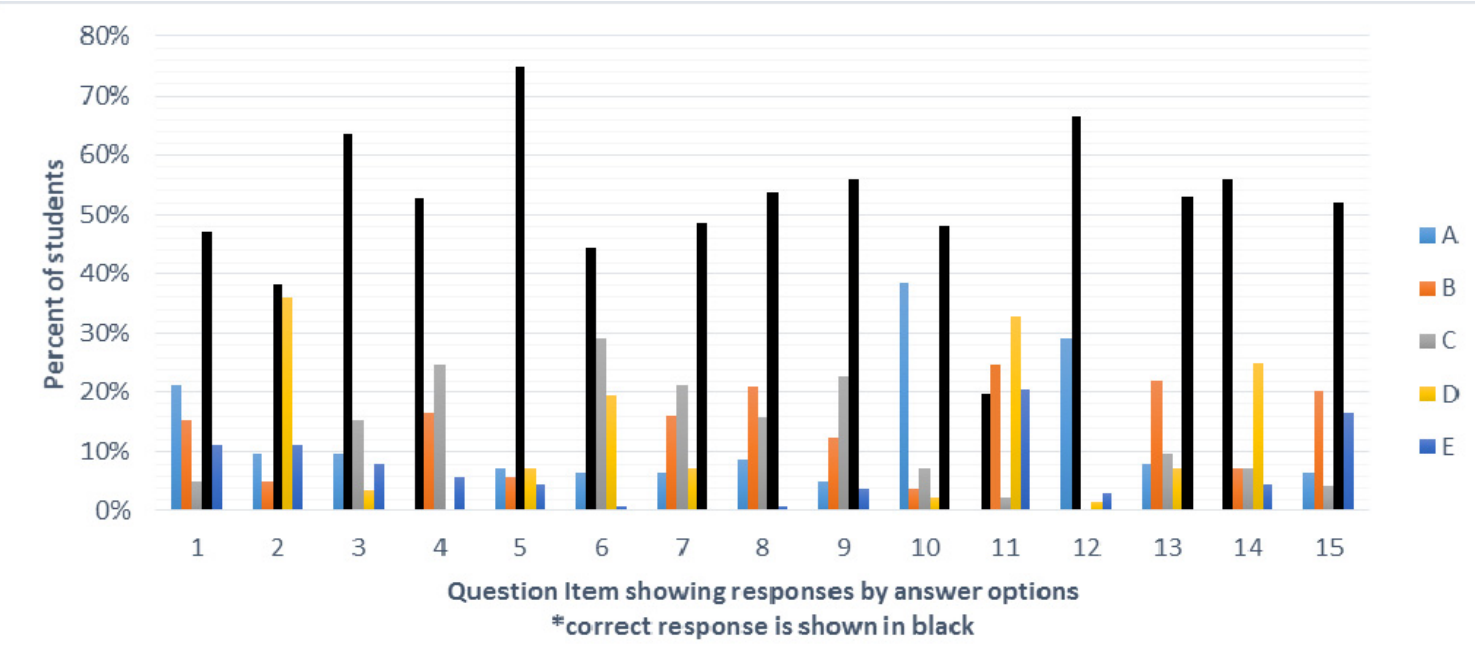

Figure 4. Student responses to ICT assessment instrument by question 


\section{Conclusion}

Information technology is ubiquitous today, and most young people in developed countries are exposed to and even immersed in technology in myriad forms. The same youths also communicate and do math before they reach school age. However, we do not assume that their exposure to language and counting means that they are proficient in reading, writing or arithmetic; we assess, remediate, amplify and re-assess the three literacies. That is not the case with digital literacy, which is often taken for granted. Moreover, many educators equate exposure with understanding. This study sought to assess the digital literacy of college seniors preparing to graduate. The findings of this study are but one dot in the complex pointillistic painting that is modern digital literacy. However, extrapolating from the study may be as straightforward as connecting those dots.

A number of broad observations can be made about the results of the digital literacy assessment. With caveats that include a small sample size and an instrument that has not undergone psychometric evaluation, it is at least anecdotally noteworthy that only $12 \%$ of the students answered $80 \%$ of the items correctly. Perhaps more illuminating still is that $72 \%$ of the students would have "failed" the assessment based on a traditional scale. The designers of the assessment did not anticipate that the students -- graduating seniors -- would have that much difficulty answering items on the instrument. These results evoked our mantra that exposure does not equal understanding with regard to students' daily interaction with digital technologies. For instance, most students likely encounter PDF documents frequently, but just under half of the respondents did not appear to understand the notion of portability in the context of that item on the instrument. Perhaps what was missing for these students was a way to anchor their exposure to PDF documents to a deeper understanding of the purpose of such files. The notion of anchors -- hooks with which technology users can bridge experience with understanding -- warrants further exploration, particularly if one posits that acquisition of these anchors is a primary purpose of education.

Clearly, institutions of higher education must better understand the digital literacy of students (Duggan, 2013; Beetham, 2010). Moreover, colleges and universities should develop coherent, inclusive and holistic digital literacy strategies (JISC, 2012a). As noted above, while national efforts to address digital literacy are underway in various countries, many educational institutions lag in their efforts to define, measure and amplify the complex construct. Digital literacy has implications for both socioeconomic status and social mobility (Media Awareness Network, 2010; European Commission, 2010; Organisation for Economic Co-operation and Development, 2013). On a national scale, there are broad implications for innovation and economic growth. Adequately addressing digital literacy -- putting it on par with the three other literacies (reading, writing and arithmetic) -- would be challenging and costly indeed. Not adequately addressing this increasingly relevant construct, however, could prove to be considerably more costly (Van Deursen \& Van Dijk, 2009) for nations and educational institutions. Given the stakes, it is imperative that governments and educators alike articulate comprehensive digital literacy strategies that reach back to the youngest students and ensure that college graduates enter the workforce armed with these critical competencies.

As noted in a recent Deakin University report (2013), digital literacy is a dynamic concept: "as ICT changes, what it means to be digitally literate also needs to evolve to ensure that students develop and apply skills in appropriate new technologies for information discovery, transfer, analysis, review and communication." Many institutions of higher education are failing to identify, assess and amplify critical digital literacy knowledge and skills -- static or dynamic. Educators must improve the foundations for digital literacy in primary education, and insist that digital literacy competencies be included in standardized college entrance examinations such as the SAT and ACT. Moreover, educators should pave the way for the fourth literacy to take its place alongside the other three literacies in the core curricula of colleges and universities. As this study inti- 
mates, universities should also assess the digital literacy of students as they near graduation. Digital literacy is essential not only in the digital workplace but in all aspects of modern life.

\section{References}

Bawden, D. (2008). Origins and concepts of digital literacy. In C. Lankshear \& M. Knobel (Eds.), Digital literacies: Concepts, policies \& practices (pp. 17-32). New York: Peter Lang.

Beetham, H. (2010). Review and scoping study for a Cross-JISC Learning and digital literacies programme. Available from http://www.jisc.ac.uk/media/documents/programmes/elearning/DigitalLiteraciesReview.pdf

Buckingham, D. (2006). Defining digital literacy: What do young people need to know about digital media? Nordic Journal of Digital Literacy, 4, 264-277.

Deakin University. (2013). Digital literacies teaching resource. Deakin University learning outcome resource guide. Deakin University, Victoria, Australia. Available from http://www.deakin.edu.au/_data/assets/pdf_file/0017/38006/digital-literacy.pdf

Department of Education, Employment and Workplace Relations (DEEWR). (2009). Transforming Australia's higher education system. Available from http://www.deewr.gov.au/HigherEducation/Documents/TransformingAusHigherED.pdf

DG Information Society and Media Group. (2008). Digital literacy report: A review for the 22010 eInclusion initiative. Available from http://www.ifap.ru/library/book386.pdf

Duncan-Howell, J. (2012). Digital mismatch: Expectations and realities of digital competency amongst preservice education students. Australasian Journal of Educational Technology, 28(5), 827-840. Available from http://www.ascilite.org.au/ajet/ajet28/duncan-howell.pdf

Duggan, F. (2013). Why universities should acquire - and teach - digital literacy. The Guardian. Available from http://www.theguardian.com/education/2013/apr/23/universities-should-teach-digitalliteracy

European Commission (2003). eLearning: Better eLearning for Europe. Directorate-General for Education and Culture, Luxembourg. Office for Official Publications of the European Communities.

European Commission (2010). Communication from the Commission to the European Parliament, the Council, the European Economic and Social Committee and the Committee of the Regions: A digital agenda for Europe. Available from http://eurlex.europa.eu/LexUriServ/LexUriServ.do?uri=CELEX:52010DC0245R\%2801\%29:EN:NOT

European Commission (2013). Digital agenda for Europe: A Europe 2020 initiative. Available from http://ec.europa.eu/digital-agenda/digital-agenda-europe

Ferrari, A. (2013). DIGCOMP: A framework for developing and understanding digital competence in Europe. Edited by Yves Punie and Barbara N. Brečko Seville: JRC-IPTS. Available from http://ftp.jrc.es/EURdoc/JRC83167.pdf

Glister, P. (1997). Digital literacy. New York: John Wiley.

Innovation and Business Skills Australia. (2013). Digital literacy and e-skills: Participation in the digital economy. Available from https://www.ibsa.org.au/sites/default/files/media/Digital\%20Literacy\%20and\%20eskills\%20Executive\%20Summary_0.pdf

JISC. (2012a). Developing digital literacies: Briefing paper. Available from http://www.jisc.ac.uk/media/documents/publications/briefingpaper/2012/Developing_Digital_Literacie s.pdf

JISC. (2012b). Developing digital literacies: A series of national workshops on developing learners and learning organisations for the 21st century. Available from 
http://www.jisc.ac.uk/whatwedo/programmes/elearning/developingdigitalliteracies/diglitworkshops.as px

JISC (2013). Developing digital literacies: Overview. Available from http://www.jisc.ac.uk/whatwedo/programmes/elearning/developingdigitalliteracies.aspx

Katz, I., \& Macklin, A. S. (2007). Information and communication technology (ICT) literacy: Integration and assessment in higher education. Systemics, Cybernetics and Informatics, 5(4), 50-55.

Martin, A. (2006). Literacies for the digital age. In A. Martin \& D. Madigan (Eds.), Digital literacies for learning (pp. 3-25). London: Facet Publishing

Martin, A., \& Grudziecki, J. (2006). DigEuLit: Concepts and tools for digital literacy development. Innovation in Teaching and Learning in Information and Computer Science, 5(4). Available from http://journals.heacademy.ac.uk/doi/abs/10.11120/ital.2006.05040249

Media Awareness Network. (2010). Digital literacy in Canada: From inclusion to transformation. A submission to the Digital Economy Strategy Consultation. Available from http://www.ic.gc.ca/eic/site/028.nsf/eng/00454.html

National Telecommunications and Information Administration US Department of Commerce. (nd). Digital Literacy.gov. Available from: http://www.digitalliteracy.gov

Organisation for Economic Co-operation and Development. (2011). Programme for international student assessment (PISA) 2009 key findings. Available from http://www.oecd.org/pisa/pisaproducts/pisa2009keyfindings.htm

Organisation for Economic Co-operation and Development. (2013). OECD skills outlook 2013: First results from the survey of adult skills. Available from http://skills.oecd.org/skillsoutlook.html

Pérez, J., \& Murray, M. (2010). Generativity: The new frontier for information and communication technology literacy. Interdisciplinary Journal of Information, Knowledge and Management, 5, 127-137. Available from http://www.ijikm.org/Volume5/IJIKMv5p127-137Perez440.pdf

US Department of Commerce (2011). Fact sheet: Digital literacy. Available from http://www.commerce.gov/news/fact-sheets/2011/05/13/fact-sheet-digital-literacy

Van Deursen, A., \& Van Dijk, J. (2009). Improving digital skills for the use of online public information and services. Government Information Quarterly, 26, 333-340.

\section{Appendix Digital Literacy Assessment Instrument}

Name:

Major:

Age:
Instructor:

Gender:

Course/Section:

Instructions: Please fill out every field above. Circle the letter next to the single best answer for each item below. The assessment continues on the back side of the page.

\section{Which of the following configurations is most likely to be found in a new personal com-} puter purchased today?
a. 6GB RAM and 500MB hard disk drive
c. $6 \mathrm{MB}$ RAM and $500 \mathrm{~GB}$ hard disk drive
b. $500 \mathrm{~GB}$ RAM and $6 \mathrm{~GB}$ hard disk drive
d. 6GB RAM and 500GB hard disk drive 

e. 500MB RAM and $6 \mathrm{~GB}$ hard disk
drive

2. In the binary code used in personal computers, a character such as the letter "J" represents one byte, which is equivalent to
a. 1
b. 2
d. 32
c. 8
e. 64 bit(s).

3. A computer's is comparable to a human's shortterm memory.
a. ROM
d. external hard drive
b. RAM
e. $\mathrm{CPU}$
c. internal hard drive

4. A motherboard is $a(n)$
a. component containing the CPU, RAM, and ROM
c. central chip that processes instructions
d. expansion card
b. case containing all internal system components
e. permanent storage device

5. $A(n)$ facilitates communication between the operating system and a peripheral such as a printer.
a. applet
d. expansion card
b. compiler
e. macro
c. device driver

6. attacks are fraudulent e-mails that appear to be from an authentic entity, such as a bank or credit card company, asking for personal information.
a. Adware
d. Virus
b. Phishing
e. Zombie
c. Spyware

7. A filename extension can be used to determine the
a. date on which the file was created
d. size of the file
b. full path of the file
e. type of application that was used to create the file
c. location of the file are privacy threats because they allow Internet adver-

8. tisers to track you and develop profiles of your web surfing history and habits.
a. First-party cookies
d. Third-party cookies
b. Pop-ups
e. Web services
c. Session cookies

9. Entering in the cell of a spreadsheet program would result in $\mathbf{4 4}$ as the calculated amount. 

a. $5 * 8+2^{\wedge} 2$
d. $=5^{*} 8+2^{\wedge} 2$
b. $\left(5^{*} 8\right)+2^{\wedge} 2$
e. $+5^{*} 8+2^{\wedge} 2$
c. $\operatorname{TOTAL}\left(5^{*} 8+2^{\wedge} 2\right)$

10. software is free and benefits from many unaffiliated programmers worldwide who modify its code to add enhancements and fix errors.
a. Shareware
d. Object-oriented
b. Proprietary
e. Open source
c. Compiled

11. Which of the following would be the best to enter into a search engine on the Web to find information about organic chemistry?
a. organic OR chemistry
d. organic chemistry
b. organic AND chemistry
e. "organic chemistry"
c. organic NOT chemistry

12. is the primary protocol of the World Wide Web.
a. HTML
d. ISP
b. HTTP
e. $T C P / I P$
c. FTP

13. WEP, WPA, and WPA2 are used to
a. defragment a hard drive
d. rip a music $C D$
b. compress a file
e. secure a wireless router
c. edit a streaming video

14. Which of the following would be a good primary key of a table in a relational database of customers?
a. customer ID
d. last name, first name, street, city,
b. last name state, zip
c. last name and first name
e. social security number

15. You are assigned the task of electronically distributing a 300-page user manual to a global network of affiliates. You know that some recipients will print the manual, whereas others will view it on a computer screen. Which of the following file formats is best suited for your task of distributing the file?
a. Hypertext Markup Language
d. Portable Document Format
b. Microsoft Word
e. Rich Text Format

c. Plain Text 


\section{Biographies}

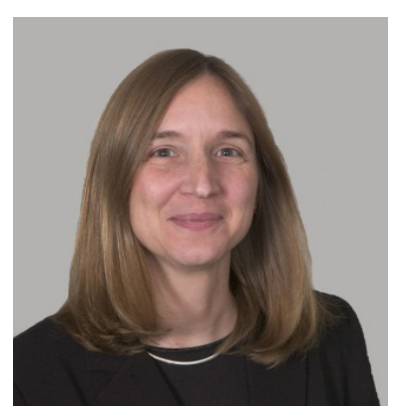

Meg Coffin Murray is a Professor of Information Systems who holds a joint appointment in the Coles College of Business and the University College at Kennesaw State University. She holds a Ph.D. in information systems and has over thirty years of experience in both academe and industry and has been the recipient of several National Science Foundation grants to enhance STEM education. Dr. Murray specializes in the development and implementation of emerging technologies to meet educational, business and societal needs. Her current work devises strategies to assess, remediate and amplify skills needed to leverage IT in innovation, a primary driver of economic growth.

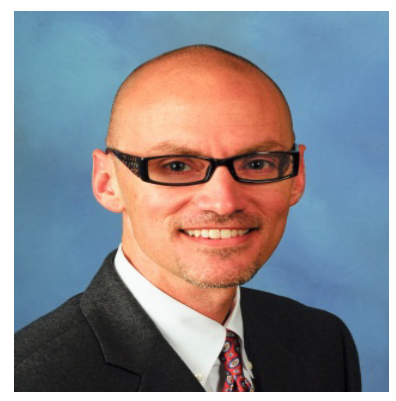

Jorge Pérez is a professor of information systems at Kennesaw State University and an American Council on Education Fellow for 20132014. He holds a Ph.D. in information systems from Florida State University and has two decades of experience as a consultant, systems analyst, web developer and educator. Professor Pérez has published research on information security, diffusion of innovations, IS education and online learning. His current research on digital literacy centers on identifying, measuring and amplifying computing competencies. 